\title{
Transient transformation of cultured photosynthetic dinoflagellates (Symbiodinium spp.) with plant-targeted vectors
}

\section{Transformación de dinoflagelados fotosintéticos del género Symbiodinium en cultivo con vectores diseñados para plantas}

\author{
Mario Fernando Ortiz-Matamoros ${ }^{1,2}$, Marco A Villanueva ${ }^{1 *}$, Tania Islas-Flores ${ }^{1 *}$ \\ ${ }^{1}$ Instituto de Ciencias del Mar y Limnología, Unidad Académica de Sistemas Arrecifales, Universidad \\ Nacional Autónoma de México (UNAM), Prol. Avenida Niños Héroes S/N, Puerto Morelos, Quintana Roo \\ 77580, México. \\ 2 Posgrado en Ciencias del Mar y Limnología-UNAM. \\ * Corresponding author. Email: tislasf@gmail.com, marco@cmarl.unam.mx
}

\begin{abstract}
Reproducible and reliable genetic transformation methods are a key tool for understanding the physiology and cell biology of Symbiodinium. Nevertheless, transformation methods previously applied to cells such as microalgae, including those utilizing glass beads, have not been tested on these microorganisms. Here, we report a simple, transient transformation method, which allowed plasmid incorporation into three distinct clades of cultured Symbiodinium cells with the plant-targeted plasmid pCB302 harboring sequences encoding a fusion of green fluorescent protein ( $g f p$ ) with RACK1C from Arabidopsis thaliana (AtRACK1C). Accessibility of the plasmid to the resistant cell wall and through the plasma membrane of the dinoflagellates was achieved through vigorous shaking in the presence of glass beads and polyethylene glycol. A resistance gene to the herbicide Basta allowed appropriate selection in the photosynthetic cells. The transformation frequency per every $10^{6}$ cells was $107 \pm 7$ transformants for Symbiodinium kawagutii, $74 \pm 8$ for Symbiodinium microadriaticum ssp. microadriaticum, and $65 \pm 5$ for Symbiodinium sp. Mf11. Moreover, Symbiodinium pulchrorum cultures were successfully transformed with a different vector (pCAMBIA-FABD2-gfp) under the same conditions, further validating our procedure. The observation of green fluorescent emission from the cell cytoplasm in all performed transformations indicated that the procedure allowed the heterologous plasmids to enter and undergo expression in the Symbiodinium cells. The success of this transient transformation method opens interesting possibilities for functional genomics studies in Symbiodinium spp.
\end{abstract}

Key words: dinoflagellates, GFP, AtRACK1C, Symbiodinium, transformation.

RESUMEN. Los métodos confiables y reproducibles de transformación genética son una herramienta clave para entender la fisiología y biología celular de Symbiodinium. Sin embargo, los métodos de transformación aplicados previamente a células tales como microalgas, incluyendo aquellos que usan perlas de vidrio, no han sido probados en Symbiodinium. Aquí reportamos un método simple de transformación transitoria que permitió la incorporación de plásmido en tres clados distintos de células de Symbiodinium en cultivo, con el plásmido pCB302 dirigido a plantas y que alberga secuencias codificantes de la fusión de proteína verde fluorescente ( $g f p$ ) con RACK1C de Arabidopsis thaliana (AtRACK1C). La accesibilidad del plásmido a la pared celular resistente y a través de la membrana plasmática de los dinoflagelados se logró mediante agitación vigorosa en presencia de perlas de vidrio y polietilenglicol. El gen que confiere resistencia al herbicida Basta permitió la selección apropiada en las células fotosintéticas. La frecuencia de transformación con este plásmido por cada $10^{6}$ células fue de $107 \pm 7$ transformantes para Symbiodinium kawagutii; $74 \pm 8$ para Symbiodinium microadriaticum ssp. microadriaticum y $65 \pm 5$ para Symbiodinium sp. Mf11. Por otra parte, los cultivos de Symbiodinium pulchrorum fueron transformados exitosamente con un vector diferente (pCAMBIAFABD2-gfp) bajo las mismas condiciones, lo cual valida aún más nuestro procedimiento. La observación de emisión verde fluorescente en el citoplasma de las células en todas las transformaciones llevadas a cabo indicó que este procedimiento permitió que los plásmidos heterólogos entraran y promovieran la expresión en las células de Symbiodinium. El éxito de este método de transformación transitoria abre posibilidades interesantes para los estudios de genómica funcional en Symbiodinium spp.

Palabras clave: dinoflagelados, GFP, AtRACK1C, Symbiodinium, transformación.

\section{INTRODUCTION}

Photosynthetic dinoflagellates of the genus Symbiodinium live in symbiosis within a wide phyletic range of marine invertebrate hosts including corals, anemones, and jellyfish. Most of Symbiodinium clades are obligate symbionts of reefbuilding corals and thus, coral reefs are highly dependent on

\section{INTRODUCCIÓN}

Los dinoflagelados fotosintéticos del género Symbiodinium viven en simbiosis con una amplia variedad filética de hospederos invertebrados marinos que incluye a corales, anémonas y medusas. La mayoría de los clados de Symbiodinium son simbiontes obligados de los corales 
the photosynthetic machinery of these microorganisms (Trench 1993). Many studies have attempted to dissect the multiple pathways by which physiological and symbiotic interaction mechanisms are controlled and regulated in these photosynthetic microorganisms. For example, there have been reports on the effect of elevated temperature on symbiosis (Gates et al. 1992), ROS-mediated bleaching (Lesser 1996, Franklin et al. 2004), origin of the symbiosome (Wakefield and Kempf 2001), coral/dinoflagellate recognition (Wood-Charlson et al. 2006), genetic differences in Symbiodinium (Loram et al. 2007), among others. However, most of these studies have been carried out using biochemical and cell biological strategies, and transcriptomics and genomics approaches have only recently been applied (Kuo et al. 2004, Chen et al. 2005, Rodriguez-Lanetty et al. 2006, Forêt et al. 2007, Leggat et al. 2007, Miller et al. 2007, Schwarz et al. 2008, Voolstra et al. 2009, Shoguchi et al. 2013, reviewed in Shinzato et al. 2014).

Transformation techniques provide a powerful tool that allows the introduction and expression of specific genes into a living organism for functional genomics studies. Thus, reproducible and reliable genetic transformation methods are a key tool for understanding the physiology and cell biology of these photosynthetic dinoflagellates. More importantly, these tools are essential to dissect and understand the cellular and molecular mechanisms underlying the cnidarian-dinoflagellate symbiosis, such as inter-partner signaling, coordination of cell division, and control of nutrient transport, and to identify target genes and their associated pathways involved in the establishment and maintenance of symbiosis. The successful transformation of microalgae via glass beads has been previously reported (Kindle 1990, León-Bañares et al. 2004); however, only one report of the transformation of cultured dinoflagellates (Symbiodinium spp.) exists to date (ten Lohuis and Miller 1998). Here, we report a simple transformation method in the presence of glass beads and polyethylene glycol (PEG), which allowed plasmid incorporation into cultured cells of the symbiotic dinoflagellate Symbiodinium. Using this procedure, we were able to transform three different cultured Symbiodinium clades along with a $\mathrm{pCB} 302$ vector harboring a construction of gfp-AtRACK1C and a resistance gene for the ammonium glufosinate-based herbicide Basta. Additionally, another Symbiodinium clade, S. pulchrorum, was transformed with a pCAMBIA-1390 vector harboring the actin-binding domain 2 of fimbrin (FABD2) fused to $g f p$ and a gene for selection with hygromycin. Microscopy revealed the successful expression of the plasmids as fluorescent cells coming from the $g f p$ hybrid proteins that was observed as the gradual appearance of yellow to green fluorescence within the cells upon selection with the herbicide Basta or hygromycin. This is the first report of the use of plant-targeted vectors, glass beads, and polyethylene glycol to transform these walled dinoflagellates. formadores de arrecife, y por ello, los arrecifes de coral son altamente dependientes de la maquinaria fotosintética de estos microorganismos (Trench 1993). Se han llevado a cabo muchos estudios que han intentado elucidar las múltiples vías por las cuales los mecanismos fisiológicos y de interacción simbiótica son controlados y regulados en estos microorganismos fotosintéticos. Por ejemplo, han habido reportes del efecto de la temperatura elevada sobre la simbiosis (Gates et al. 1992), del blanqueamiento mediado por ROS (Lesser 1996, Franklin et al. 2004), del origen del simbiosoma (Wakefield y Kempf 2001), del reconocimiento coraldinoflagelado (Wood-Charlson et al. 2006), de las diferencias genéticas en Symbiodinium (Loram et al. 2007), entre otros. Sin embargo, la mayoría de estos estudios se han llevado a cabo usando estrategias bioquímicas y de biología celular, y las estrategias genómicas y transcriptómicas, sólo han sido aplicadas recientemente (Kuo et al. 2004, Chen et al. 2005, Rodriguez-Lanetty et al. 2006, Forêt et al. 2007, Leggat et al. 2007, Miller et al. 2007, Schwarz et al. 2008, Voolstra et al. 2009, Shoguchi et al. 2013, revisado en Shinzato et al. 2014).

Las técnicas de transformación proveen una herramienta poderosa que permite la introducción y expresión de genes específicos en un organismo vivo para estudios de genómica funcional. De esta manera, los métodos reproducibles y confiables de transformación genética son una herramienta clave para entender la fisiología y biología celular de estos dinoflagelados fotosintéticos. En un aspecto más importante, estas herramientas son esenciales para analizar y entender los mecanismos celulares y moleculares subyacentes a la simbiosis entre cnidarios y dinoflagelados, como la señalización intersocio, la coordinación de la división celular y el control del transporte de nutrientes, y para identificar genes blanco y sus vías asociadas involucradas en el establecimiento y mantenimiento de la simbiosis. La transformación exitosa de microalgas mediante perlas de vidrio ha sido documentada previamente (Kindle 1990, León-Bañares et al. 2004); sin embargo, a la fecha sólo existe un reporte de la transformación de los dinoflagelados del género Symbiodinium en cultivo (ten Lohuis y Miller 1998). En este trabajo reportamos un método simple de transformación en presencia de perlas de vidrio y polietilenglicol (PEG), lo cual permitió la incorporación de plásmido en las células dinoflageladas simbióticas del género Symbiodinium en cultivo. Usando este procedimiento, fuimos capaces de transformar tres diferentes clados de Symbiodinium en cultivo con un vector pCB302 que contenía una construcción de gfp-AtRACK1C y un gen de resistencia para el herbicida Basta basado en glufosinato de amonio. Adicionalmente, otro clado de Symbiodinium, S. pulchrorum fue transformado con un vector pCAMBIA1390 que contenía el dominio 2 de unión a actina de la fimbrina ( $F A B D 2)$ fusionado a $g f p$ y a un gen para selección con higromicina. La microscopía reveló la expresión exitosa de las proteínas $g f p$ híbridas, que fue observada como la aparición gradual de fluorescencia amarilla a verde dentro de las células, al momento de la selección con el herbicida Basta 


\section{MATERIALS AND METHODS}

\section{Symbiodinium cell cultures}

Dinoflagellate cultures of Symbiodinium kawagutii Trench \& Blank (from now on referred to as S. kawagutii), Symbiodinium sp. Mf11.5b.1 (from now on referred to as S. Mf11), Symbiodinium microadriaticum ssp. microadriaticum (from now on referred to as S. KB8), and Symbiodinium pulchrorum R.K. Trench (from now on referred to as S. pulchrorum), were routinely maintained in our laboratory in ASP-8A medium under photoperiod cycles of $12 \mathrm{~h}$ light/ dark at $25^{\circ} \mathrm{C}$, and light intensity of $80 \mu \mathrm{mol}$ quanta $\mathrm{m}^{-2} \mathrm{~s}^{-1}$ (Castillo-Medina et al. 2013). For the success of the transformations, the cultures had to be axenic. This was achieved by supplementing the ASP-8A medium with $50 \mu \mathrm{g} \mathrm{mL}^{-1}$ kanamycin and $5 \mu \mathrm{g} \mathrm{mL}^{-1}$ amphotericin B (ASP-8A-M). All cultures were manipulated under sterile conditions at all times until mounting for microscopic observations.

\section{Assessment of growth of three Symbiodinium cell cultures in the presence of herbicide containing ammonium glufosinate}

Symbiodinium kawagutii, S. Mf11, and S. KB8 cells $\left(1 \times 10^{5}\right.$ cells $\left.\mathrm{mL}^{-1}\right)$ in the logarithmic growth phase were incubated in ASP-8A medium with $1 \mathrm{mg} \mathrm{mL}^{-1}$ of the ammonium glufosinate herbicide. Cell densities were estimated by counting in duplicate with a hemocytometer (Hausser Scientific, Horsham, PA) every 2-3 days. All culture treatments were performed in triplicate. Data are presented as the mean \pm standard deviation.

\section{Plasmid constructs}

A pCB302 plasmid was constructed to harbor a fusion of gfp and AtRACK1C. The AtRACK1C gene cloned in a pUNI51 vector (clone U13308) was a kind gift from the Salk Institute. The AtRACK1C coding sequence was PCR amplified and inserted in the binary vector pCB302. The plasmid construct was maintained and propagated in the Escherichia coli strain TOP10. This construction contained a double CaMV35S promoter from the cauliflower mosaic virus and the bar gene for Basta herbicide resistance (fig. 1). The pCAMBIA-1390 binary vector (Cambia Labs, Brisbane, Australia) harboring a sequence encoding the $F A B D 2$ fused to a gfp mutated at S65T (sGFP but referred to as GFP; Wang et al. 2004) was a kind gift from Dr. Elison Blancaflor (Samuel Roberts Noble Foundation, Ardmore, OK). This construct has kanamycin and hygromycin resistance genes, and the FABD2-gfp fusion is under the control of the CaMV35S promoter. Plasmids were purified using the DNA purification system Wizard Plus SV Minipreps (Promega Corporation, Madison, WI), according to the manufacturer's instructions. o higromicina. Este es el primer reporte del uso de vectores dirigidos a plantas, perlas de vidrio y polietilenglicol para transformar estos dinoflagelados con pared celular.

\section{MATERIALES Y MÉTODOS}

\section{Cultivos de células de Symbiodinium}

Los cultivos de dinoflagelados de Symbiodinium kawagutii Trench \& Blank (de ahora en adelante referido como S. kawagutii, Symbiodinium sp. Mf11.5b.1 (de ahora en adelante referido como $S$. Mf11), Symbiodinium microadriaticum ssp. microadriaticum (de ahora en adelante referido como S. KB8) y Symbiodinium pulchrorum R.K. Trench (de ahora en adelante referido como $S$. pulchrorum), fueron rutinariamente mantenidos en nuestro laboratorio en medio ASP$8 \mathrm{~A}$ bajo fotoperiodos cíclicos de $12 \mathrm{~h} \mathrm{luz} /$ oscuridad a $25^{\circ} \mathrm{C}$, y una intensidad de luz de $80 \mu \mathrm{mol}$ quanta $\mathrm{m}^{-2} \mathrm{~s}^{-1}$ (CastilloMedina et al. 2013). Para el éxito de la transformación se requirió que los cultivos fueran axénicos. Esto fue logrado suplementando el medio ASP-8A con $50 \mu \mathrm{g} \mathrm{mL} \mathrm{m}^{-1}$ de kanamicina y $5 \mu \mathrm{g} \mathrm{mL} \mathrm{mL}^{-1}$ de anfotericina B (ASP-8A-M). Todos los cultivos fueron manipulados en condiciones estériles en todo momento hasta el montaje para las observaciones en el microscopio.

\section{Determinación del crecimiento de tres cultivos celulares de Symbiodinium en presencia de un herbicida que contiene glufosinato de amonio}

Las células de $S$. kawagutii, S. Mf11, y S. KB8 $\left(1 \times 10^{5}\right.$ células $\left.\mathrm{mL}^{-1}\right)$, en fase logarítmica de crecimiento, fueron incubadas en medio ASP-8A con $1 \mathrm{mg} \mathrm{mL}^{-1}$ del herbicida glufosinato de amonio. Las densidades celulares fueron estimadas mediante conteo por duplicado con un hemocitómetro (Hausser Scientific, Horsham, PA) cada 2-3 días. Todos los tratamientos de los cultivos se llevaron a cabo por triplicado. Los datos se presentan como la media \pm la desviación estándar.

\section{Construcciones de plásmidos}

Un plásmido pCB302 fue construido para contener una fusión de gfp y AtRACK1C. El gen de AtRACK1C clonado en un vector pUNI51 (clona U13308) fue una amable donación del Instituto Salk. La secuencia codificante de AtRACK1C fue amplificada mediante PCR e insertada en el vector binario pCB302. La construcción fue mantenida y propagada en la cepa TOP10 de Escherichia coli. Esta construcción contiene un promotor doble CaMV35S del virus del mosaico de la coliflor y el gen bar para la resistencia al herbicida Basta (fig. 1). El vector binario pCAMBIA-1390 (Cambia Labs, Brisbane, Australia) que contiene la secuencia codificante de FABD2 fusionado a la gfp mutada en S65T (sGFP pero referida como GFP, Wang et al. 2004) fue una amable donación 


\section{Symbiodinium spp. transformation}

We attempted a transformation method for Symbiodinium and Amphidinium previously reported by ten Lohuis and Miller (1998), but we substituted the silicon carbide (SiC) whiskers for glass beads to produce abrasion of the wall. Transformations of S. kawagutii, S. Mf11 and S. KB8 were carried out by placing $1.3 \times 10^{7}$ cells in $1 \mathrm{~mL}$ culture medium in a $2 \mathrm{~mL}$ conical bottom plastic tube (Denville Scientific, Inc., Metuchen, NJ) containing a dry volume of $200 \mu \mathrm{L}$ (approximately $500 \mathrm{mg}$ ) acid-washed, sterile glass beads (Cat. No. G8772; 425-600 $\mu \mathrm{m}$ mesh size; Sigma, St. Louis, MO). Then, the suspension was added with $350 \mu \mathrm{L}$ of $20 \%$ PEG-3500 (Sigma), followed by $50 \mu \mathrm{L}$ containing $25 \mu \mathrm{g}$ of the plasmid to yield a final volume of $1.4 \mathrm{~mL}$ excluding the glass bead volume. The tube was vigorously shaken (4200 rpm) in a bead beater for $90 \mathrm{~s}$. Following this plasmid exposure, the cells were left to recover in ASP-8A medium for $24 \mathrm{~h}$. The transformed cells were then selected by adding $1 \mathrm{mg} \mathrm{mL}^{-1}$ Basta (Bayer, Research Triangle Park, NC) and $50 \mu \mathrm{g} \mathrm{mL}^{-1}$ kanamycin to the culture medium. The cultures were maintained in the same solution under the standard photoperiod conditions and monitored for the appearance of green fluorescence. For transformation frequency assessment, the initial cell count $\left(1.3 \times 10^{7}\right)$ of the culture used for the transformation was taken as the total for normalization. Three different observations were made from $10 \mu \mathrm{L}$ aliquots (for each of the three evaluated transformed cell cultures) after selection, and green fluorescent cells were quantitated from each sample. The scored cell numbers were converted to cell concentration and extrapolated to the total cell number by multiplying times the total volume $(25 \mathrm{~mL})$. The total numbers from each triplicate culture were averaged and scored as the mean \pm standard error. The transformation frequency was reported as this number per every $10^{6}$ cells. Alternatively, the pCAMBIA-1390 FABD2-gfp construction was transformed in $S$. pulchrorum as described above but $3 \mathrm{mg} \mathrm{mL}^{-1}$ hygromycin in the culture medium was used to select the transformed cells. Transformation frequency was not assessed on this culture.

\section{Microscopy}

Cells were observed by phase contrast and epifluorescence microscopy under a Zeiss Axioskop 40 microscope (Carl Zeiss, Göttingen, Germany) with $40 \times$ and $63 \times$ objectives using the FITC excitation/emission filter. Data were acquired using a Canon PowerShot A640 camera (Canon Inc., Japan) and the AxioVision software (Carl Zeiss). Deconvolution was performed with the DeconvolutionLab plugin of the NIH-ImageJ program using the TikhonovMiller algorithm.

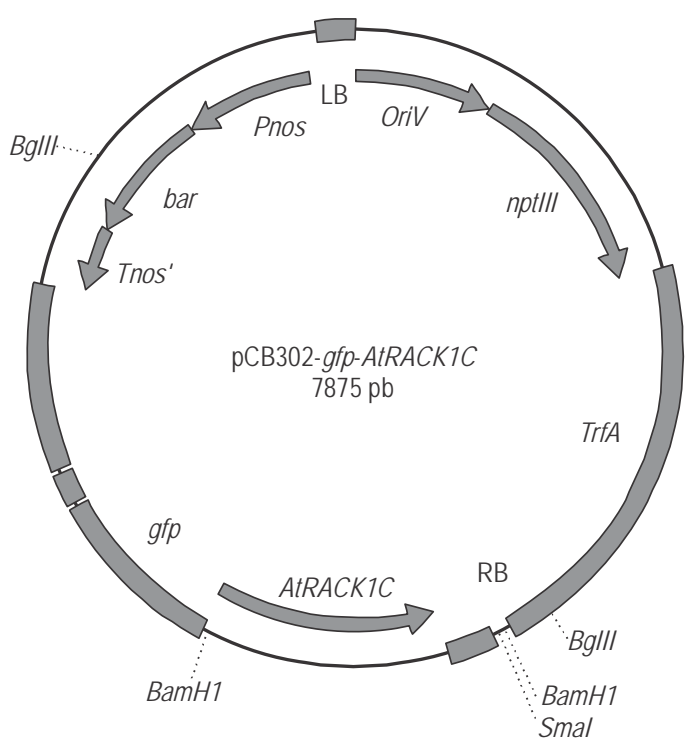

Figure 1. Diagram showing the main features of the plasmid pCB302-gfp-AtRACK1C.

Figura 1. Diagrama que muestra las principales características del plásmido pCB302-gfp-AtRACK1C.

del Dr. Elison Blancaflor (Samuel Roberts Noble Foundation, Ardmore, OK). Esta construcción tiene genes de resistencia a kanamicina e higromicina, y la fusión FABD2-gfp está bajo el control del promotor CaMV35S. Los plásmidos fueron purificados usando el sistema de purificación para ADN Wizard Plus SV Minipreps (Promega Corporation, Madison, WI), de acuerdo con las instrucciones del fabricante.

\section{Transformación de Symbiodinium spp.}

Se intentó un método de transformación para Symbiodinium y Amphidinium registrado previamente por ten Lohuis y Miller (1998), pero sustituimos las fibras de carburo de silicio $(\mathrm{SiC})$ por perlas de vidrio para producir abrasión de la pared. Las transformaciones de S. kawagutii, S. Mf11 y $S$. KB8 se realizaron colocando $1.3 \times 10^{7}$ células en $1 \mathrm{~mL}$ de medio de cultivo en un tubo de plástico de $2 \mathrm{~mL}$ con fondo cónico (Denville Scientific, Inc., Metuchen, NJ) que contenía un volumen seco de $200 \mu \mathrm{L}$ (aproximadamente $500 \mathrm{mg}$ ) de perlas de vidrio lavadas con ácido y estériles (Cat. No. G8772; 425-600 $\mu \mathrm{m}$ de tamaño de malla; Sigma, St. Louis, MO). Después, la suspensión se adicionó con $350 \mu \mathrm{L}$ de 20\% polietilenglicol (PEG-3500, Sigma), seguido de $50 \mu \mathrm{L}$ que contenían $25 \mu \mathrm{g}$ de plásmido para alcanzar un volumen final de $1.4 \mathrm{~mL}$ excluyendo el volumen de las perlas de vidrio. Después, el tubo fue agitado vigorosamente (4200 rpm) durante $90 \mathrm{~s}$ en un batidor de partículas (bead beater). Seguido a esta exposición al plásmido, las células se dejaron recuperando en medio ASP-8A por $24 \mathrm{~h}$. Luego, las células transformadas fueron seleccionadas mediante la adición de $1 \mathrm{mg} \mathrm{mL}^{-1}$ de Basta (Bayer, Research Triangle 


\section{RESULTS}

\section{Successful and reproducible Symbiodinium transformation}

When we applied our modified procedure to three different Symbiodinium clades, the green fluorescence from the GFP-AtRACK1C expression was observed in some of the cells after 8-26 days in the selection medium (ASP-8A culture medium with Basta, fig. 2a-f). We mostly observed the red autofluorescence from the photosynthetic pigments and a few green fluorescent cells in S. kawagutii (fig. 2b) and S. KB8 (fig. 2d) cultures, but more green fluorescent cells were observed in S. Mf11 cultures at this stage (fig. 2f), indicating that the glass beads were effective in breaking the wall, allowing the plasmid to be delivered and expressed inside the cells. Using this method, we successfully reproduced and obtained a transformation rate per every $10^{6}$ cells of $65 \pm 5$ for $S$. Mf11, $74 \pm 8$ for $S$. KB8, and $107 \pm 7$ for S. kawagutii. Although only a few transformed S. kawagutii cells were observed at an early selection stage (fig. 2b), we observed that this clade was the most susceptible to transformation as it consistently yielded the highest number of green fluorescent cells after full selection (data not shown), which was reflected in its higher transformation frequency (107 \pm 7 transformants per every $10^{6}$ cells). The herbicide containing ammonium glufosinate as the active compound, effectively promoted non-transformed cell death (fig. 3). On the contrary, Symbiodinium-transformed cells that carried the bar resistance gene were able to survive after incubation in selection medium with $1 \mathrm{mg} \mathrm{mL}^{-1}$ Basta.

To further substantiate our findings and the reproducibility of the procedure, we transformed another expression vector (pCAMBIA-1390-FABD2-gfp) in a different Symbiodinium clade, S. pulchrorum, with a plasmid harboring a different resistance gene (hygromycin). Our transformation method with these variants was also successful and we were able to obtain transformed cells by selection in ASP-8A medium containing hygromycin (fig. 4a, upward arrow, and $4 \mathrm{~b}, \mathrm{~d})$. At an early selection stage, we observed a mixture of non-transformed red fluorescent cells (fig. $4 \mathrm{a}$, downward arrow) and transformed ones (fig. 4a, upward arrow), even though both were identical under phase contrast optics (fig. 4c, arrows). When full selection was achieved, observation of transformed cells under epifluorescence at higher magnification revealed a fluorescent reticular gridtype pattern of mostly thick bundles of microfilaments (fig. 4d, arrowhead). These results indicated that the transient transformation could be achieved on a different Symbiodinium phylotype using a plant-targeted vector different from pCB302.

\section{DisCUSSION}

In this work, we have successfully applied, for the first time, a glass bead-mediated transformation procedure on
Park, NC) y $50 \mu \mathrm{g} \mathrm{mL}^{-1}$ de kanamicina al medio de cultivo. Los cultivos fueron mantenidos en la misma solución bajo condiciones estándar de fotoperiodo y monitoreados para la aparición de fluorescencia verde. Para determinar la frecuencia de transformación, el conteo celular inicial $\left(1.3 \times 10^{7}\right)$ del cultivo usado para la transformación fue tomado como el total para la normalización. Se hicieron tres diferentes observaciones de alícuotas de $10 \mu \mathrm{L}$ (para cada uno de los cultivos transformados evaluados) después de la selección, y las células verdes fluorescentes fueron cuantificadas en cada muestra. El número de células cuantificadas fue convertido a concentración de células y extrapolado al número de células totales multiplicando por el volumen total $(25 \mathrm{~mL})$. Los números totales de cada cultivo triplicado fueron promediados y se registró la media \pm el error estándar. La frecuencia de transformación fue registrada como éste número por cada $10^{6}$ células. Alternativamente, la construcción pCAMBIA1390 FABD2-gfp fue transformada en $S$. pulchrorum como se describió anteriormente pero usando $3 \mathrm{mg} \mathrm{mL}^{-1}$ de higromicina en el medio de cultivo para seleccionar a las células transformadas. La frecuencia de transformación no se determinó en este cultivo.

\section{Microscopía}

Las células fueron observadas bajo contraste de fases y epifluorescencia en un microscopio Zeiss Axioskop 40 (Carl Zeiss, Göttingen, Alemania) con los objetivos de $40 \times$ y $63 \times$ y el filtro de excitación/emisión de FITC. Los datos fueron adquiridos con una cámara Canon PowerShot A640 (Canon Inc., Japan) y el programa AxioVision (Carl Zeiss). La deconvolución fue realizada con el complemento DeconvolutionLab del programa NIH-ImageJ usando el algoritmo Tikhonov-Miller.

\section{RESULTADOS}

\section{Transformación exitosa y reproducible de Symbiodinium}

Cuando aplicamos nuestro procedimiento modificado a tres diferentes clados de Symbiodinium, pudimos observar, en algunas de las células, la fluorescencia verde de la expresión de GFP-AtRACK1C después de 8-26 días en el medio de selección (medio de cultivo ASP-8A con Basta, fig. 2a-f). En los cultivos de S. kawagutii (fig. 2b) y $S$. KB8 (fig. 2d) observamos mayormente células con fluorescencia roja proveniente de los pigmentos fotosintéticos y algunas células verdes fluorescentes, pero en los cultivos de $S$. Mf11 observamos más células verdes fluorescentes en esta etapa (fig. 2f), indicando que las perlas de vidrio fueron efectivas para romper la pared celular, lo cual permitió la entrada del plásmido y su expresión dentro de las células. Usando este método, reproducimos exitosamente y obtuvimos una tasa de transformación por cada $10^{6}$ células de $65 \pm 5$ para $S$. Mf11, $74 \pm 8$ para $S$. KB8 y $107 \pm 7$ para S. kawagutii. Aunque sólo 

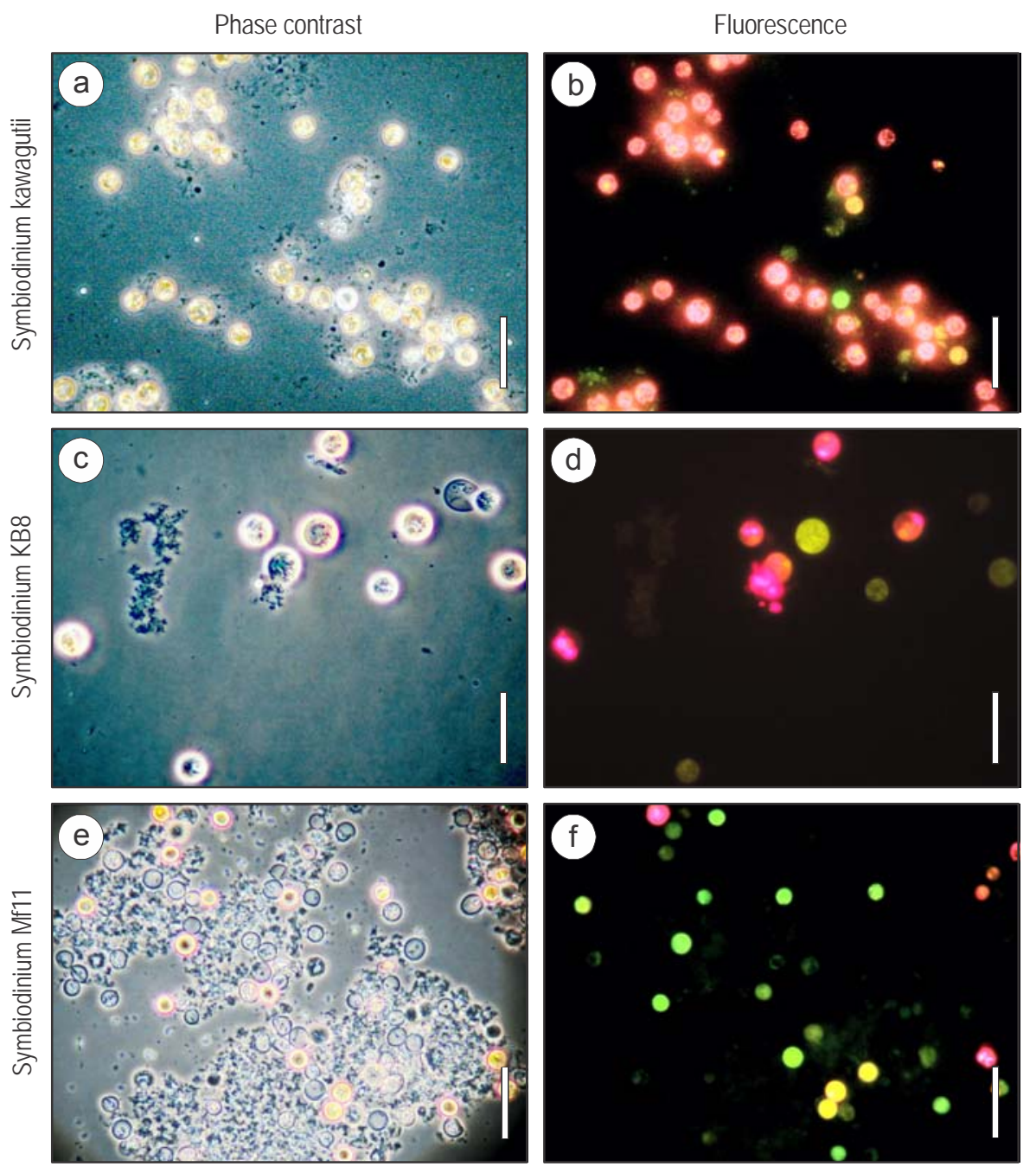

Figure 2. Glass bead-, PEG-mediated transformation with the plasmid pCB302-gfp-AtRACK1C in Symbiodinium spp. The cells of Symbiodinium kawagutii (a, b), Symbiodinium KB8 (c, d), and Symbiodinium Mf11 (e, f) were transformed using glass beads, PEG, and the pCB302-gfp-AtRACK1C plasmid. Cells were observed under phase contrast (a, c, e) and epifluorescence microscopy (b, d, f) after 8 (a, b), $25(\mathbf{c}, \mathbf{d})$, or $26(\mathbf{e}, \mathbf{f})$ days of selection with Basta. Bars equal $30 \mu \mathrm{m}(\mathbf{a}, \mathbf{b}), 20 \mu \mathrm{m}(\mathbf{c}, \mathbf{d})$, and $25 \mu \mathrm{m}(\mathbf{e}, \mathbf{f})$.

Figura 2. Transformación mediada por perlas de vidrio y PEG con el plásmido pCB302-gfp-AtRACK1C en Symbiodinium spp. Las células de Symbiodinium kawagutii (a, b), Symbiodinium KB8 (c, d) y Symbiodinium Mf11 (e, f) fueron transformadas usando perlas de vidrio, PEG y el plásmido pCB302-gfp-AtRACK1C. Las células fueron observadas bajo microscopía de contraste de fases (a, c, e) y epifluorescencia $(\mathbf{b}, \mathbf{d}, \mathbf{f})$ después de $8(\mathbf{a}, \mathbf{b}), 25(\mathbf{c}, \mathbf{d})$ ó $26(\mathbf{e}, \mathbf{f})$ días de selección con Basta. Las barras equivalen a $30 \mu \mathrm{m}(\mathbf{a}, \mathbf{b})$, $20 \mu \mathrm{m}(\mathbf{c}, \mathbf{d})$ y $25 \mu \mathrm{m}(\mathbf{e}, \mathbf{f})$.

cultured Symbiodinium cells. To date only one report of Symbiodinium transformation exists (ten Lohuis and Miller 1998), and there are no further reports on its reproducibility and/or application by other groups. These authors reported the transformation of the dinoflagellates Amphidinium sp. and Symbiodinium microadriaticum Freudenthal. They used plasmid constructs containing the neomycin phosphotransferase (nptII) and the hygromycin B phosphotransferase (hpt) resistance genes, with $\beta$-glucoronidase as the reporter gene, and obtained an efficiency of 5-24 transformants per every $10^{7}$ cells with their method. We were able to reproduce that transformation procedure with the slight modification of the unas pocas células transformadas de $S$. kawagutii fueron observadas en un estado temprano de selección (fig. 2b), nosotros observamos que este clado fue el más susceptible a la transformación, pues consistentemente alcanzó el número más alto de células verdes fluorescentes después de la selección completa (datos no mostrados). Esto se reflejó en su mayor frecuencia de transformación (107 \pm 7 transformantes por cada $10^{6}$ células). El herbicida con glufosinato de amonio como el componente activo efectivamente promovió la muerte de las células no transformadas (fig. 3). Por el contrario, las células de Symbiodinum transformadas que albergaban el gen de resistencia bar fueron capaces de 

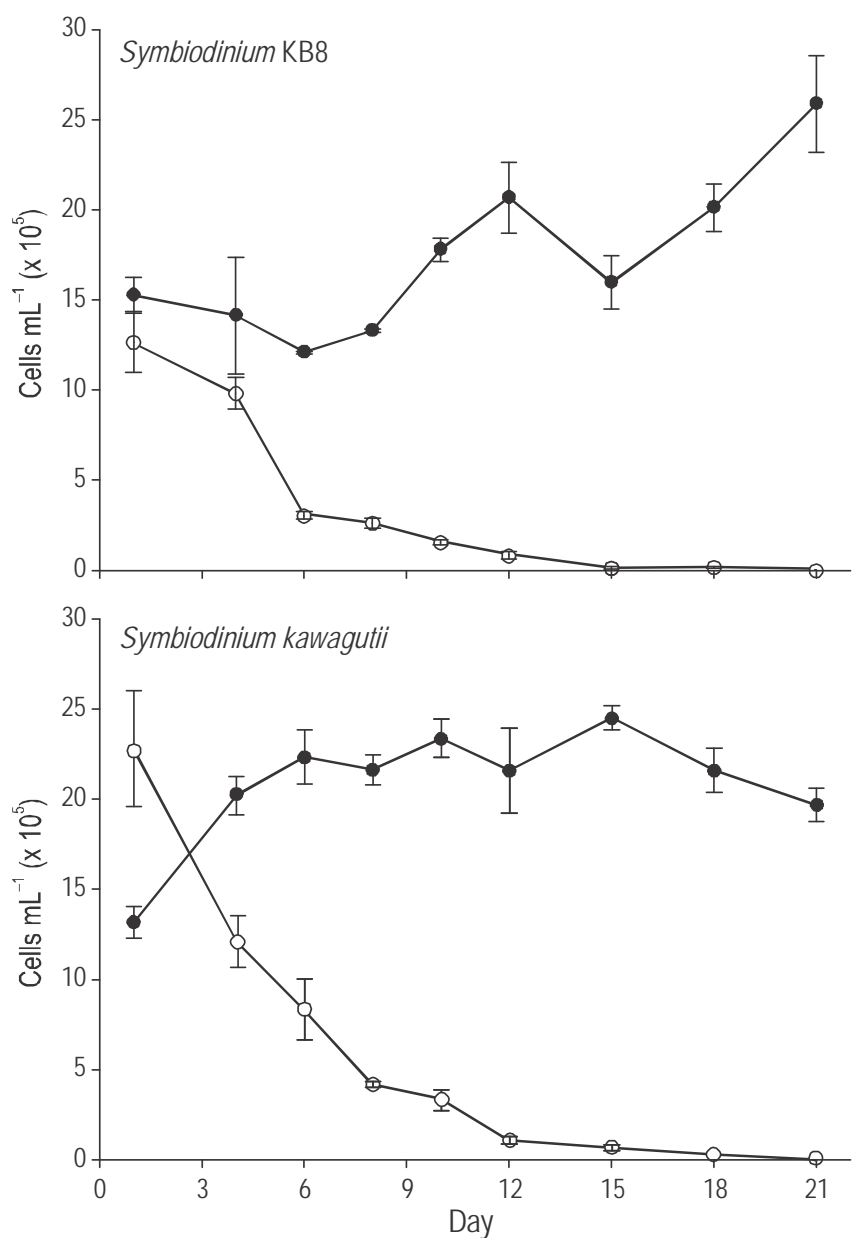

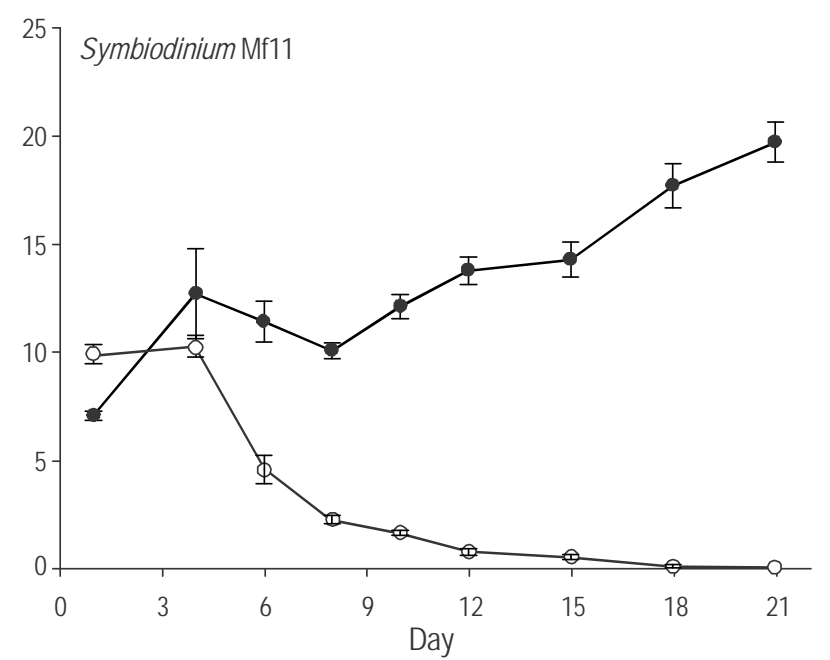

- ASP-8A

O ASP-8A $+1 \mathrm{mg} \mathrm{mL}^{-1}$ herbicide

Figure 3. Assessment of the growth of Symbiodinium cell cultures in the presence of a herbicide containing ammonium glufosinate. (a) Symbiodinium KB8, (b) Symbiodinium Mf11, and (c) Symbiodinium kawagutii cells. Solid line: cells in ASP-8A medium; dashed line: cells in ASP-8A medium with $1 \mathrm{mg} \mathrm{mL}^{-1}$ ammonium glufosinate. The cell count was conducted every $2-3$ days using a hemocytometer during a 21-day period. Cultures were performed and analyzed in triplicate. Data are presented as the mean \pm standard deviation.

Figura 3. Determinación del crecimiento de cultivos de células de Symbiodinium en presencia del herbicida con glufosinato de amonio. Células de (a) Symbiodinium KB8, (b) Symbiodinium Mf11 y (c) Symbiodinium kawagutii. Línea sólida: células en medio ASP-8A; línea discontinua: células en medio ASP-8A con $1 \mathrm{mg} \mathrm{mL}^{-1}$ de glufosinato de amonio. El conteo celular fue realizado usando un hemocitómetro cada 2-3 días durante 21 días. Los cultivos fueron crecidos y analizados por triplicado. Los datos son presentados como la media \pm desviación estándar.

use of glass beads instead of $\mathrm{SiC}$ whiskers since we considered that the glass beads would produce the same effect as the $\mathrm{SiC}$ whiskers without their drawback of low transformation efficiency (Songstad et al. 1995) and the health hazard that they represent (Dunahay et al. 1997). In addition, glass beads are inexpensive and non-toxic. Consequently, a transformation procedure with this material is simple and does not require access to specialized equipment.

Indeed, we obtained successful transformations of the Symbiodinium cells using plasmid introduction via glass beads with higher efficiency (up to $107 \pm 7$ per every $10^{6}$ cells) than that of the previously reported procedure (5-24 per every $10^{7}$ cells; ten Lohuis and Miller 1998). It is important to note that many tests were carried out in which either the glass beads or PEG, or both were omitted in the sobrevivir después de la incubación en medio de selección con $1 \mathrm{mg} \mathrm{mL}^{-1}$ de Basta.

Para apoyar aún más nuestros hallazgos y la reproducibilidad del método, transformamos otro vector de expresión (pCAMBIA-1390-FABD2-gfp) en un clado diferente de Symbiodinium, S. pulchrorum, con un plásmido que contenía un gen de resistencia distinto (higromicina). Nuestro método de transformación con estas variantes fue también exitoso y fuimos capaces de obtener células transformadas mediante la selección en el medio ASP-8A que contenía higromicina (fig. 4a, flecha hacia arriba, y 4b, d). En un estado temprano de selección, observamos una mezcla de células fluorescentes rojas no transformadas (fig. 4a, flecha hacia abajo) y células transformadas (fig. 4a, flecha hacia arriba), aun cuando ambas fueron idénticas bajo óptica de contraste de 

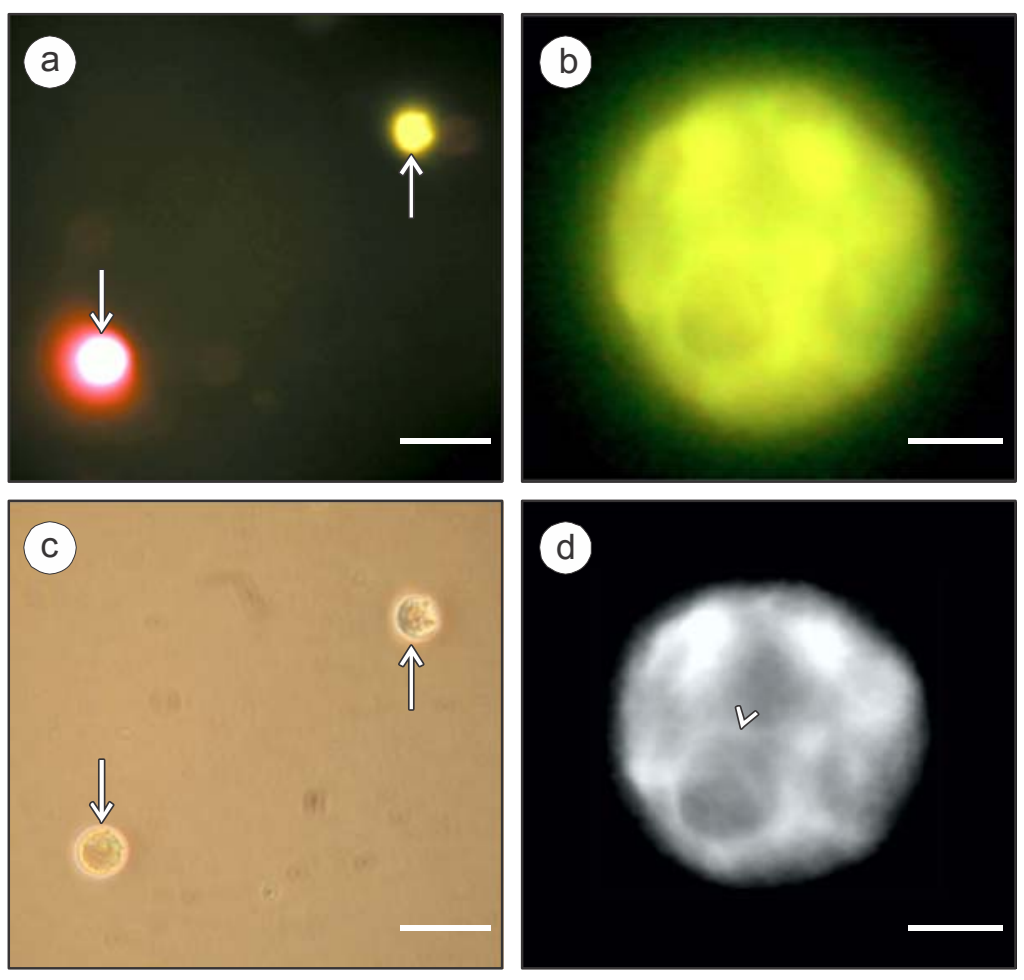

Figure 4. In vivo labeling of the actin cytoskeleton in Symbiodinium pulchrorum cells by transformation with a pCAMBIA-1390-FABD2-gfp expression vector (Wang et al. 2004). Conventional epifluorescence images of S. pulchrorum cells after transformation with FABD2-gfp $(\mathbf{a}, \mathbf{b}, \mathbf{d})$. At an early selection stage in medium with hygromycin, a mixed population of transformed yellow (a, upward arrow) and nontransformed red (a, downward arrow) cells was detected. Phase contrast optics (c) showed no difference between the same transformed and non-transformed cells. After full selection, observations at higher magnification revealed a grid-type pattern of thick microfilament bundles (d, arrowhead). The image in (b) was subjected to deconvolution (see Materials and Methods), which yielded the image with improved resolution in (d). Bars equal $30 \mu \mathrm{m}(\mathbf{a}, \mathbf{c})$ and $5 \mu \mathrm{m}(\mathbf{b}, \mathbf{d})$.

Figura 4. Marcaje in vivo del citoesqueleto de actina en células de Symbiodinium pulchrorum por transformación con un vector de expresión pCAMBIA-1390-FABD2-gfp (Wang et al. 2004). Imágenes de epifluorescencia convencional de células de S. pulchrorum después de la transformación con FABD2-gfp $(\mathbf{a}, \mathbf{b}, \mathbf{d})$. En un estado de selección temprana en medio con higromicina, se detectó una población mezclada de células amarillas transformadas (a, flecha hacia arriba) y rojas no transformadas (a, flecha hacia abajo). La óptica de contraste de fases (c) no mostró diferencia entre las mismas células transformadas y no transformadas. Después de la selección completa, las observaciones a mayor aumento revelaron un patrón tipo rejilla de haces gruesos de microfilamentos (d, cabeza de flecha). La imagen en (b) estuvo sujeta a deconvolución (ver Materiales y Métodos), lo cual resultó en una imagen con resolución mejorada en (d). Las barras equivalen a 30 m (a, c) y a $5 \mu \mathrm{m}(\mathbf{b}, \mathbf{d})$.

transformation protocol, without success (data not shown). Another important observation was the fact that the cultures had to be rendered axenic by the use of antibiotics in order to obtain a successful and contaminant-free transformation. This was possible because it is known that Symbiodinium cultures are resistant to several antibiotics (ten Lohuis and Miller 1998, Soffer et al. 2008).

As reported previously for the expression of the GUS reporter and hpt genes (ten Lohuis and Miller 1998), the CAMV35S and nos promoters were sufficient and efficient to drive the expression of the gene constructs harboring the fused $g f p$ sequences and the bar and hpt genes from the pCB302 and pCAMBIA-1390 vectors, respectively. Thus, these promoters could be used for the future design of expression vectors in Symbiodinium. fases (fig. 4c, flechas). Cuando la selección completa fue lograda, la observación bajo epifluorescencia de las células transformadas, a mayor aumento, reveló un patrón reticular fluorescente tipo rejilla de haces gruesos de microfilamentos en su mayoría (fig. 4d, cabeza de flecha). Estos resultados indicaron que la transformación transitoria pudo ser lograda en un filotipo diferente de Symbiodinium usando un vector dirigido a plantas diferente de pCB302.

\section{DISCUSIÓN}

En este trabajo, hemos aplicado exitosamente, por primera vez, un procedimiento de transformación mediado por perlas de vidrio a células de Symbiodinium en cultivo. A la fecha solamente existe un reporte de transformación de 
Since Symbiodinium cells are photosynthetic and pCB302 vectors contain the bar gene for resistance to ammonium glufosinate-based herbicides, we hypothesized that this herbicide (conventionally used to select transformed plant cells) would be similarly metabolized and represented a good selection agent for transformed Symbiodinium cells. Glufosinate inhibits the activity of the enzyme glutamine synthetase resulting in a rapid accumulation of ammonium and inhibition of photosynthesis (Wendler et al. 1990), whereas expression of the bar gene (which encodes the enzyme phosphinothricin $\mathrm{N}$-acetyltransferase), results in the rapid conversion of glufosinate to the non-phytotoxic metabolite N-acetyl-L-glufosinate and confers resistance to the herbicide in the transformed cells. This was probably also true for Symbiodinium cells since incubation of different clades of wild-type Symbiodinum cells in the presence of this type of herbicide promoted cell death (fig. 3); on the contrary, transformed cells with the pCB302 plasmid harboring the bar resistant gene survived. It should be noted that in usual transformed plant selection with Basta, a concentration of $20 \mathrm{mg} \mathrm{L}^{-1}$ herbicide is commonly used (Akama et al. 1995). Since we observed that this concentration was not sufficient for the selection of the transformed Symbiodinium cells, we raised the concentration of Basta to $1 \mathrm{mg} \mathrm{mL}^{-1}$, which was not harmful to the transformed cells, and a good selection was achieved.

The Basta-treated transformed cultures showed a mixture of red, chlorophyll-containing (non-transformed) cells and green (transformed) cells (fig. $2 b, d, f$ ). At the end of the selection process, almost all the transformed cells showed the green fluorescence and the amount of red fluorescent cells was minimal. The observed fluorescence showed a pattern of staining suggestive of cytoplasmic localization as would be expected for RACK1 and other signaling proteins.

At the end of the selection process, the overexpression of proteins fused to GFP produced fluorescent greenish-looking Symbiodinium cells under the epifluorescence microscope; this was unusual since the combination of the red fluorescent chlorophyll and GFP should have resulted in fluorescent orange-yellow-looking cells. In addition, we observed both intermediate fluorescence colors and intermediate pigmentation in the cells during the selection process. Although we have no data to explain the reason for this observation, one possibility is that the overexpression itself of proteins fused to GFP may affect the pathways leading to the synthesis of chlorophyll and/or similar photosynthetic pigments. In fact, this would not be an unusual effect in the RACK1transformed cells, since it is a scaffold protein that can interact with a wide range of signaling proteins and regulate physiological processes such as cell division, signaltransduction, and metabolic pathways (reviewed in Adams et al. 2011). The effect of heterologous RACK1 overexpression in Symbiodinium and its possible involvement in photosynthetic pigment metabolism merits further research.
Symbiodinium (ten Lohuis y Miller 1998), y no existen reportes posteriores de su reproducibilidad y/o aplicación por otros grupos. Estos autores documentaron la transformación de los dinoflagelados Amphidinium sp. y Symbiodinium microadriaticum Freudenthal. Ellos usaron construcciones de plásmidos que contenían los genes de resistencia codificantes para neomicina fosfotransferasa (nptII) e higromicina fosfotransferasa (hpt), con $\beta$-glucoronidasa como el gen reportero, y obtuvieron una eficiencia de 5-24 transformantes por cada $10^{7}$ células con su método. Nosotros pudimos reproducir ese método de transformación con la leve modificación del uso de perlas de vidrio en lugar de fibras de $\mathrm{SiC}$, ya que consideramos que las perlas de vidrio producirían el mismo efecto que las fibras de $\mathrm{SiC}$ sin sus desventajas de baja eficiencia de transformación (Songstad et al. 1995) ni el peligro a la salud que ellas representan (Dunahay et al. 1997). Además, las perlas de vidrio son baratas y no tóxicas. Consecuentemente, un procedimiento de transformación con este material es simple y no requiere del acceso a equipo especializado.

En efecto, nosotros obtuvimos transformaciones exitosas de las células de Symbiodinium introduciendo el plásmido mediante perlas de vidrio con mayor eficiencia (hasta $107 \pm 7$ por cada $10^{6}$ células) que aquella del procedimiento registrado previamente (5-24 por cada $10^{7}$ células; ten Lohuis y Miller 1998). Es importante notar que muchas pruebas se llevaron a cabo sin éxito en las cuales, ya sea las perlas de vidrio, el PEG, o ambos fueron omitidos en el protocolo de transformación (datos no mostrados). Otra observación importante fue el hecho de que los cultivos tuvieron que mantenerse axénicos mediante el uso de antibióticos a fin de lograr una transformación exitosa y libre de contaminantes. Esto fue posible porque se sabe que los cultivos de Symbiodinium son resistentes a varios antibióticos (ten Lohuis y Miller 1998, Soffer et al. 2008).

Tal como se registró previamente para la expresión de los genes reporteros GUS y hpt (ten Lohuis y Miller 1998), los promotores CaMV35S y nos fueron suficientes y eficientes para conducir la expresión de las construcciones génicas que contenían las secuencias de $g f p$ fusionadas, y de los genes bar y hpt de los vectores pCB302 y pCAMBIA-1390, respectivamente. De esta manera, estos promotores podrían ser usados para el diseño futuro de vectores de expresión en Symbiodinium.

Debido a que las células de Symbiodinum son fotosintéticas y que los vectores pCB302 contienen el gen bar para la resistencia a herbicidas a base de glufosinato de amonio, nosotros hipotetizamos que este herbicida (usado convencionalmente para seleccionar plantas y células vegetales transformadas) sería metabolizado de manera similar y representaba un buen agente de selección para células de Symbiodinium transformadas. El glufosinato inhibe la actividad de la enzima glutamina sintetasa, lo que resulta en una rápida acumulación de amonio e inhibición de la fotosíntesis (Wendler et al. 1990), mientras que la expresión del gen bar (el cual codifica para la enzima fosfinotricina $\mathrm{N}$-acetil 
In addition to the use of the $\mathrm{pCB} 302$ vector with Basta resistance, we sought to prove the reproducibility of the procedure by transforming a different Symbiodinium clade, S. pulchrorum, with another expression vector harboring an alternative construction and selection cassette that could provide a different type of associated fluorescence pattern. Our selection approach was to reproduce the susceptibility of Symbiodinium to the antibiotic hygromycin that was exploited in the previous transformation report (ten Lohuis and Miller 1988). In an analogous manner to the selection with Basta, the selection process with hygromycin was successful as a mixture of transformed and non-transformed cells were detected at early selection stages (fig. 4a), and all of them displayed yellow fluorescence at the later selection stages (fig. 4b, d). Further evidence of heterologous expression was the fact that the transformed cells observed under epifluorescence revealed a reticular grid-type pattern of heavily bundled microfilaments. The organization patterns were different from those observed with the GFP-AtRACK1C expression and very similar to what has been observed with FITC-phalloidin and anti-actin antibodies in S. kawagutii cells (Villanueva et al. 2014). Taken together, our data demonstrate that foreign gene introduction to different Symbiodinium clades with two distinct expression vectors harboring different resistance genes, mediated by vigorous shaking with glass beads and PEG, provide a successful and reproducible procedure for transiently transforming Symbiodinium spp. in a simple manner.

Functional genomics approaches have not yet been applied to Symbiodinium precisely due to the lack of a reproducible and reliable transformation method for these cells, and the procedure reported in this study should alleviate this problem. Glass bead-mediated transformation methods have the significant advantage of producing acceptable rates of transformation over other available genetic-transformation protocols. Our present work further confirms that the application of glass bead-mediated transformation in the presence of PEG results in a viable method for introducing genes of interest in Symbiodinium spp., and makes this method an option for their genetic transformation.

\section{ACKNOWLEDGMENTS}

This work was suported by grants PAPIIT IN-210514 from DGAPA-UNAM and 175951 from the National Council for Science and Technology (CONACYT, Mexico) to MAV. MFO was supported by a PhD scholarship (No. 131280) from CONACYT. TIF was supported by a postdoctoral fellowship from DGAPA-UNAM. We thank Claudia Morera and Patricia Rueda for technical help.

\section{REFERENCES}

Adams DR, Ron D, Kiely PA. 2011. RACK1, A multifaceted scaffolding protein: Structure and function. Cell Commun. Signal. 9: 22 . transferasa) resulta en la rápida conversión del glufosinato al metabolito no fitotóxico N-acetil L-glufosinato, y confiere resistencia al herbicida en las células transformadas. Esto probablemente también fue cierto para las células de Symbiodinium ya que la incubación de diferentes clados de células tipo silvestre de Symbiodinium en presencia de este tipo de herbicida promovió muerte celular (fig. 3); por el contrario, las células transformadas con el plásmido pCB302 que contenía el gen de resistencia bar sobrevivieron. Debe notarse que en la selección usual con Basta de plantas transformadas, comúnmente se utiliza una concentración de $20 \mathrm{mg} \mathrm{L}^{-1}$ del herbicida (Akama et al. 1995). Ya que observamos que esta concentración no fue suficiente para la selección de las células transformadas de Symbiodinum, aumentamos la concentración de Basta hasta $1 \mathrm{mg} \mathrm{mL}^{-1}$, la cual no fue dañina para las células transformadas, y obtuvimos una buena selección.

Las células transformadas tratadas con Basta mostraron una mezcla de células rojas conteniendo clorofila (no transformadas) y células verdes (transformadas) (fig. 2b, d, f). Al final del proceso de selección, casi todas las células transformadas mostraron la fluorescencia verde y la cantidad de células con fluorescencia roja fue mínima. La fluorescencia observada mostró un patrón sugerente de localización citoplásmica, como se esperaría para RACK1 y otras proteínas de señalización.

Al final de la selección, la sobreexpresión de las proteínas fusionadas a GFP produjo células de Symbiodinium fluorescentes con apariencia verduzca bajo el microscopio de epifluorescencia. Esto fue inusual ya que la combinación de la fluorescencia roja de la clorofila y la GFP debió haber resultado en células fluorescentes de apariencia naranaja-amarilla. Además, observamos colores de fluorescencia intermedia y pigmentación intermedia en las células durante el proceso de selección. Aunque no tenemos datos que expliquen esta observación, una posibilidad es que la sobreexpresión en sí misma de las proteínas fusionadas a GFP podría afectar a las vías que llevan a la síntesis de la clorofila y/o pigmentos fotosintéticos similares. De hecho, esto no sería un efecto inusual en las células transformadas con RACK1, ya que esta es una proteína de andamiaje que puede interactuar con un amplio rango de proteínas de señalización y regular procesos fisiológicos como la división celular, transducción de señales y rutas metabólicas (revisado en Adams et al. 2011). El efecto de la sobreexpresión heteróloga de RACK1 en Symbiodinium y su posible relación con el metabolismo de pigmentos fotosintéticos amerita mayor investigación.

Además del uso del vector pCB302 con resistencia a Basta, nos dimos a la tarea de probar la reproducibilidad del procedimiento transformando un clado diferente de Symbiodimiun, S. pulchrorum, con otro vector de expresión que contenía una construcción y una caja de selección alternas que pudieran proporcionar un tipo diferente de patrón de fluorescencia asociado. Nuestra estrategia de selección fue reproducir la susceptibilidad de Symbiodinium 
Akama K. Puchta H, Hohn B. 1995. Efficient Agrobacteriummediated transformation of Arabidopsis thaliana using the bar gene as selectable marker. Plant Cell Rep. 14: 450-454.

Castillo-Medina R, Islas-Flores T, Thomé PE, Iglesias-Prieto R, Lin S, Zhang H, Villanueva MA. 2013. The PsbO homolog from Symbiodinium kawagutii (Dinophyceae) characterized using biochemical and molecular methods. Photosynthesis Res. 115: $167-178$

Chen MC, Hong MC, Huang YS, Liu MC, Cheng YM, Fang LS. 2005. ApRab11, a cnidarian homologue of the recycling regulatory protein Rab11, is involved in the establishment and maintenance of the Aiptasia-Symbiodinium endosymbiosis. Biochem. Biophys. Res. Commun. 338: 1607-1616.

Dunahay TG, Adier SA, Jarvik JW. 1997. Methods in Molecular Biology. Humana Press, Totowa, New Jersey, pp. 503-509.

Forêt S, Kassahn KS, Grasso LC, Hayward DC, Iguchi A, Ball EE, Miller DJ. 2007. Genomic and microarray approaches to coral reef conservation biology. Coral Reefs 26: 475-486.

Franklin DJ, Hoegh-Guldberg O, Jones RJ, Berges JA. 2004. Cell death and degeneration in the symbiotic dinoflagellates of the coral Stylophora pistillata during bleaching. Mar. Ecol. Prog. Ser. 272: 117-130.

Gates RD, Baghdasarian G, Muscatine L. 1992. Temperature stress causes host cell detachment in symbiotic cnidarians: Implications for coral bleaching. Biol. Bull. 182: 324-332.

Kindle KL. 1990. High-frequency nuclear transformation of Chlamydomonas reinhardtii. Proc. Natl. Acad. Sci. USA 87: 1228-1232.

Kuo J, Chen MC, Lin CH, Fang LS. 2004. Comparative gene expression in the symbiotic and aposymbiotic Aiptasia pulchella by expressed sequence tag analysis. Biochem. Biophys. Res. Commun. 318: 176-186.

Leggat W, Hoegh-Guldberg O, Dove S, Yellowlees D. 2007. Analysis of an EST library from the dinoflagellate (Symbiodinium sp.) symbiont of reef-building corals. J. Phycol. 43: 1010-1021.

León-Bañares R, González-Ballester D, Galván A, Fernández E. 2004. Transgenic microalgae as green cell-factories. Trends Biotechnol. 22: 45-52.

Lesser MP. 1996. Elevated temperatures and ultraviolet radiation cause oxidative stress and inhibit photosynthesis in symbiotic dinoflagellates. Limnol. Oceanogr. 41: 271-283.

Loram JE, Trapido-Rosenthal HG, Douglas AE. 2007. Functional significance of genetically different symbiotic algae Symbiodinium in a coral reef symbiosis. Mol. Ecol. 16: 4849-4857.

Miller D, Hemmrich G, Ball EE, Hayward DC, Khalturin K, Funayama N, Agata K, Bosch TC. 2007. The innate immune repertoire in Cnidaria - ancestral complexity and stochastic gene loss. Genome Biol. 8: R59.

Rodriguez-Lanetty M, Phillips W, Weis V. 2006. Transcriptome analysis of a cnidarian - dinoflagellate mutualism reveals complex modulation of host gene expression. BMC Genomics 7: 23 .

Schwarz JA, Brokstein PB, Voolstra C, Terry AY, Miller DJ, Szmant AM, Coffroth MA, Medina M.2008. Coral life history and symbiosis: Functional genomic resources for two reef building Caribbean corals, Acropora palmata and Montastraea faveolata. BMC Genomics 9: 97.

Shinzato C, Mungpakdee S, Satoh N, Shoguchi E. 2014. A genomic approach to coral-dinoflagellate symbiosis: Studies of Acropora digitifera and Symbiodinium minutum. Front. Microbiol. 5: 336.

Shoguchi E, Shinzato C, Kawashima T, Gyoja F, Mungpakdee S, Koyanagi R, Takeuchi T, Hisata K, Tanaka M, Fujiyama A, al antibiótico higromicina que fue previamente explotado en el reporte previo de transformación (ten Lohuis y Miller 1988). De manera análoga a la selección con Basta, el proceso de selección con higromicina fue exitoso, pues una mezcla de células transformadas y no transformadas fue detectada en las etapas tempranas de selección (fig. 4a), y todas ellas mostraron fluorescencia amarilla en estados posteriores (fig. 4b, d). Otra evidencia de expresión heteróloga fue el hecho de que las células transformadas observadas bajo epifluorescencia mostraron un patrón reticular tipo rejilla de microfilamentos aglomerados densamente. El patrón de organización fue diferente a aquel observado con la expresión de GFP-AtRACK1C y muy similar a lo que ha sido observado con FITC-faloidina y anticuerpos antiactina en S. kawagutii (Villanueva et al. 2014). En conjunto, nuestros datos demuestran que la introducción de genes foráneos a diferentes clados de Symbiodinium con dos vectores distintos de expresión conteniendo genes de resistencia diferentes, mediada por la agitación vigorosa con perlas de vidrio y PEG, proporciona un procedimiento exitoso y reproducible para la transformación transitoria de Symbiodinium spp. de una manera simple.

Las estrategias de genómica funcional todavía no han sido aplicadas a Symbiodinium debido precisamente a la falta de un método reproducible y confiable para estas células, y el procedimiento reportado en este trabajo debe aliviar este problema. Los métodos de transformación mediados por perlas de vidrio tienen la ventaja importante de producir tasas aceptables de transformación sobre otros protocolos de transformación genética disponibles. El presente trabajo además confirma que la aplicación de la transformación mediada por perlas de vidrio y PEG resulta en un método viable para introducir genes de interés en Symbiodinium spp., y que este método es una opción para su transformación genética.

\section{Agradecimientos}

Este trabajo fue apoyado por los donativos PAPIIT IN210514 de DGAPA-UNAM y 175951 del Consejo Nacional de Ciencia y Tecnología (CONACYT, México) a MAV. MFO fue apoyado con la beca de doctorado (No. 131280) de CONACYT. TIF fue apoyada con la beca postdoctoral de DGAPA-UNAM. Agradecemos a Claudia Morera y Patricia Rueda el apoyo técnico.

Medina M, Coffroth MA, Bhattacharya D, Satoh N. 2013. Draft assembly of the Symbiodinium minutum nuclear genome reveals dinoflagellate gene structure. Curr. Biol. 23: 1399-1408.

Soffer N, Gibbs PDL, Baker AC. 2008. Practical applications of contaminant-free Symbiodinium cultures grown on solid media. Proc. 11th International Coral Reef Symposium, pp. 159-163.

Songstad DD, Somers DA, Griesbach RJ. 1995. Advances in alternative DNA delivery techniques. Plant Cell Tiss. Organ Cult. 40: 1-15. 
ten Lohuis MR, Miller DJ. 1998. Genetic transformation of dinoflagellates (Amphidinium and Symbiodinium): Expression of GUS in microalgae using heterologous promoter constructs. Plant J. 13: 427-435.

Trench RK. 1993. Microalgal-invertebrate symbioses: A review. Endocyt. Cell Res. 9: 135-175.

Villanueva MA, Arzápalo-Castañeda G, Castillo-Medina RE. 2014. The actin cytoskeleton organization and disorganization properties of the photosynthetic dinoflagellate Symbiodinium kawagutii in culture. Can. J. Microbiol. 60: 767-775.

Voolstra CR, Schwarz JA, Schnetzer J, Sunagawa S, Desalvo MK, Szmant AM, Coffroth MA, Medina M. 2009. The host transcriptome remains unaltered during the establishment of coral-algal symbioses. Mol. Ecol. 18: 1823-1833.
Wakefield TS, Kempf SC. 2001. Development of host- and symbiont-specific monoclonal antibodies and confirmation of the origin of the symbiosome membrane in a cnidarian-dinoflagellate symbiosis. Biol. Bull. 200: 127-143.

Wang Y-S, Motes CM, Mohamalawari DR, Blancaflor EB. 2004. Green fluorescent protein fusions to Arabidopsis fimbrin 1 for spatio-temporal imaging of F-actin dynamics in roots. Cell Motil. Cytoskeleton 59: 79-93.

Wendler C, Barniske M, Wild A. 1990. Effect of phosphinothricin (glufosinate) on photosynthesis and photorespiration of $\mathrm{C} 3$ and C4 plants. Photosynth. Res. 24: 55-61.

Wood-Charlson EM, Hollingsworth LL, Krupp DA, Weis VM. 2006. Lectin/glycan interactions play a role in recognition in a coral/ dinoflagellate symbiosis. Cell. Microbiol. 8: 1985-1994.

Received August 2014, accepted December 2014. 